\title{
Use of NIR spectroscopy on fresh apples to determine the phenolic compounds and dry matter content in peel and
} flesh

\author{
Audrey Pissard ${ }^{(1)}$, Vincent Baeten ${ }^{(2)}$, Pierre Dardenne ${ }^{(2)}$, Pascal Dupont ${ }^{(1)}$, Marc Lateur ${ }^{(1)}$ \\ (1) CRA-W (Walloon Agricultural Research Centre). Life Sciences Department. Rue de Liroux, 4. BE-5030 Gembloux \\ (Belgium). E-mail: a.pissard@ cra.wallonie.be \\ (2) CRA-W (Walloon Agricultural Research Centre). Valorisation of Agricultural Products Department. Chaussée de Namur, \\ 24. BE-5030 Gembloux (Belgium).
}

Received 6 May 2016, accepted 29 September 2017, available online 6 October 2017.

This article is distributed under the terms and conditions of the CC-BY License (http://creativecommons.org/licenses/by/4.0)

Description of the subject. The article deals with the use of near-infrared spectroscopy (NIR) on fresh apples to determine the phenolic compounds and dry matter content in peel and flesh powders.

Objectives. The aim is the rapid and non-destructive determination of these nutritional parameters.

Method. Two hundred twenty-nine fruits from 20 varieties were analyzed with NIR spectroscopy and reference methods.

Results. Great variability of total phenolic compounds (TPC) in peel and flesh powders was observed among varieties. The dry matter (DM) content also differed greatly between peel and flesh. Calibration and validation models showed high coefficients of determination for the TPC content, which were slightly higher for the peel than for the flesh $\left(\mathrm{R}^{2} \mathrm{val}=0.91\right.$ and 0.84 respectively). For the DM content, high coefficients of determination and ratios of prediction to deviation (RPDs) were also observed $\left(\mathrm{R}^{2} \mathrm{val}=0.94, \mathrm{RPD}=4.8\right.$ and $\mathrm{R}^{2} \mathrm{val}=0.94, \mathrm{RPD}=4.9$ for the peel and flesh respectively).

Conclusions. Calibration and validation models allow quantitative predictions to be made for TPC and DM content. They confirm the potential of NIRS for predicting the polyphenol content and highlight its potential for determining the DM content, a parameter often neglected in research into apple quality.

Keywords. Apples, peel, infrared spectrophotometry, phenolic content, dry matter content.

Utilisation de la spectroscopie NIR sur les pommes pour déterminer les teneurs en polyphénols et en matière sèche de la pelure et de la chair des fruits

Description du sujet. L'article traite de l'utilisation de la spectroscopie proche infrarouge (NIR) sur les pommes pour déterminer les teneurs en polyphénols totaux et en matière sèche des poudres de pelure et de chair du fruit.

Objectifs. Le but est de pouvoir déterminer de façon rapide et non destructive ces composés nutritionnels.

Méthode. Deux-cent-vingt-neuf fruits provenant de 20 variétés ont été analysés par spectroscopie NIR et avec les méthodes de référence.

Résultats. Une grande variabilité du contenu en polyphénols a été observée au sein des variétés. La teneur en matière sèche est également très variable et diffère entre la pelure et la chair. Les modèles de calibration et validation ont montré de hauts coefficients de détermination pour la teneur en polyphénols totaux, légèrement plus élevée pour la pelure que pour la chair $\left(\mathrm{R}^{2} \mathrm{val}=0,91\right.$ et 0,84 pour la pelure et la chair respectivement). Pour la teneur en matière sèche, de hauts coefficients de détermination et de hauts rapports RPD ont également été observés $\left(\mathrm{R}^{2} \mathrm{val}=0,94, \mathrm{RPD}=4,8\right.$ et $\mathrm{R}^{2} \mathrm{val}=0,94, \mathrm{RPD}=4,9$ pour la pelure et la chair respectivement).

Conclusions. Les modèles développés permettent des prédictions quantitatives des teneurs en polyphénols totaux et en matière sèche. Ces résultats confirment le potentiel de la spectroscopie NIR pour prédire la teneur en polyphénols totaux et met en évidence son potentiel pour déterminer la matière sèche, un paramètre souvent négligé dans la recherche sur la qualité des pommes.

Mots-clés. Pomme, pelure, spectroscopie infrarouge, teneur en phénols, teneur en matière sèche. 


\section{INTRODUCTION}

There has been an increasing appreciation and understanding of the link between dietary fruit and health benefits for humans (Hyson, 2011). Apple is one of the most consumed fruits in the world. In 2012, world apple production was estimated at around 76 million tonnes according to the Food and Agriculture Organization (FAO, 2013). The average consumption of apples in the EU is $15 \mathrm{~kg}$ per person, and although apple consumption is declining in Europe, worldwide consumption of apples is growing. As they are commonly eaten, particularly in Europe and North America, in various forms (e.g. fresh fruit, juice, cider, compote) and throughout the year, they constitute a large contributor of phytochemicals in the human diet.

Apple fruits, and especially the peel, contain many phenolic compounds which are naturally occurring plant secondary metabolites. Flavanols (catechins and procyanidins) are the major class of apple polyphenols, followed by hydroxycinnamates, flavonols, dihydrochalcones and, in red apples, anthocyanins (Vrhovsek et al., 2004; Wojdylo et al., 2008). Polyphenol content and composition depend on variety, fruit maturity, agricultural practices, growing year, storage period and processing (Awad et al., 2000; Van der Sluis et al., 2002; Markowski \& Plocharski, 2006; Lata, 2007). However, genotype and tissue type (peel $v s$ flesh) are probably the most important factors determining the content of phenolics (Tsao et al., 2003; Verberic et al., 2005). Higher concentrations of total phenolic compounds have been found in the peel than in the flesh, and some compounds (quercetin glucosides) have been found mainly in the peel (Awad et al., 2000; Van der Sluis et al., 2002; Verberic et al., 2005). The absence of flavonols in the flesh of several varieties, including 'Gala' and 'Jonagold' apples, has been reported in the literature (Van der Sluis et al., 2001; Khanizadeh et al., 2007). Anthocyanins, mainly cyanidin-3-galactoside, are also mainly located in apple peel in red or partially red cultivars (Khanizadeh et al., 2007). Conversely, hydroxycinnamic acids, in particular chlorogenic acid, have been found in higher concentration in the flesh than in the peel in all varieties (except 'Reinette Russet') (Khanizadeh et al., 2007). Awad et al. (2000) also showed the low level of chlorogenic acid in the peel compared to the core area.

In addition to their important function as plant defence mechanisms against external stresses, phenolic compounds also contribute to the taste, quality and colour of fruits and their products (Van der Sluis et al., 2002; Lattanzio, 2003). The polyphenol composition and total antioxidant capacity of apples have been studied by several authors (Van der Sluis et al., 2002; Verberic et al., 2005). It has been reported that flavonoids such as quercetin, epicatechin, and procyanidin B2, rather than vitamin $\mathrm{C}$, contribute significantly to overall antioxidant activities in apples (Lee et al., 2003). Regular consumption of apples provides a large amount of polyphenolic compounds such as flavanols (procyanidins and catechins), dihydrochalcones (phloridzin), hydroxycinnamic acids (chlorogenic acid and p-coumaroylquinic acid), flavonols (quercetin), and anthocyanins. Phenolic compounds are of great interest to consumers, especially in terms of health. The benefits of these apple phytochemicals have been widely reviewed (Boyer \& Liu, 2004; Hyson, 2011). Finally, phytonutrients and antioxidant compounds not only determine fruit's nutritional and nutraceutical features but are also related to its potential storability (Verberic et al., 2005).

The Walloon Agricultural Research Centre (CRAW) has been investigating its large fruit genetic resources collection since 1973 (Lateur \& Populer, 1994; Lateur, 2003). This multi-annual research program has several objectives, including heritage conservation and the evaluation, conservation and use of the fruit. Researches currently focus on the selection and use of varieties that have low susceptibility to diseases and are adapted to lowinput production modes and of varieties with specific nutritional properties (e.g. with a high content of ascorbic acid and/or phenolic compounds). The study of the quality and nutritional properties of fruit (sugar, ascorbic acid, malic acid, fibres and phenolic compounds content) is one of the institution's main areas of expertise (Planchon et al., 2004). Over the past few years, the use of near-infrared spectroscopy (NIRS) has been investigated in order to develop a rapid and non-destructive tool for the determination of the quality and nutritional parameters of apples (Pissard et al., 2012; Pissard et al., 2013).

Up-to-date research on the use of NIRS on apples has mainly focused on determining the soluble solids content, firmness and acidity (McGlone et al., 2002; Mehinagic et al., 2003; Park et al., 2003; Peirs et al., 2003; Sanchez et al., 2003; Zude et al., 2006; Paz et al., 2009; Bobelyn et al., 2010). Recently, the possibility of using mid-infrared spectroscopy for the determination of sugars, acids and polyphenols contents has been evaluated and a Vis-NIR portable system has been tested for the determination of apples' nutraceutic properties (Bureau et al., 2012; Beghi et al., 2013).

This study was performed as part of a program of activities aiming to make effective use of the high level of bioactive compounds in the fruit genetic resources collection. NIRS was used to evaluate the vitamin $\mathrm{C}$ and polyphenol content in apples (Pissard 
et al., 2013). In order to study and take advantage of the quality parameters of fruit, the use of NIRS for rapid determination of the polyphenol and dry matter content in powdered apple peel and flesh was investigated. So far as we know, this is the first study focusing on determining total polyphenols by NIRS in the peel and flesh of apples separately. This original approach is supported by the great variability of concentration in both parts of the fruit (i.e. peel and flesh) and between different varieties.

\section{MATERIALS AND METHODS}

\subsection{Samples}

A total of 229 fruits from 20 apple varieties were studied (Table 1). Varieties were chosen to cover the broad variability of the CRA-W's collections. Fruit samples were picked from orchards in Gembloux (Belgium) under temperate climate conditions.
Old, commercial, and cider varieties, and a few cultivars from our breeding program, were sampled in 2009 . Fruits of each variety were collected at optimal ripening time. Fruits were picked randomly from the outer layer of the trees, avoiding fruits with atypical features (atypical size for example).

\subsection{Chemical and NIRS measurements}

The fresh fruits were first individually analysed by near-infrared spectroscopy. The spectra were acquired using a FOSS NIRSystems 6500 scanning monochromator covering the visible and NIR range $(408-2,498 \mathrm{~nm}, 2 \mathrm{~nm})$. To take account of the variability of the fruit, four measurements were performed by rotating the apple and averaged to provide a mean spectrum for each apple (Pissard et al., 2012). Next, fruits were individually analysed by reference methods. The flesh and peel of the fruits were separated using a mechanical apple peeler. A thin layer of apple flesh remained adhered to the

Table 1. Content of total phenolic compounds (TPC) in peel and flesh powder of apples (expressed in $\mu \mathrm{g} \mathrm{GAE} \cdot \mathrm{g}^{-1}$ fresh weight), peel/flesh ratio and dry matter (DM) content in peel and flesh $\left(\mathrm{g} \cdot \mathrm{kg}^{-1}\right)$ - Teneur en polyphenols totaux (TPC) dans la poudre de pelure et de chair de pommes (exprimée en $\mu \mathrm{g} G A E \cdot \mathrm{g}^{-1}$ poids frais), rapport pelure/chair et contenu en matière sèche dans la pelure et chair $\left(\mathrm{g} \cdot \mathrm{kg}^{-1}\right)$.

\begin{tabular}{lllllclll}
\hline Nb & Variety & Type & Fruits & $\begin{array}{l}\text { Peel TPC } \\
\left(\mu \mathrm{g} \cdot \mathrm{g}^{-1} \mathrm{FW}\right)\end{array}$ & $\begin{array}{l}\text { Flesh TPC } \\
\left(\mu \mathrm{g} \cdot \mathrm{g}^{-1} \mathrm{FW}\right)\end{array}$ & $\begin{array}{l}\text { Ratio } \\
\text { peel/flesh }\end{array}$ & $\begin{array}{l}\text { Peel DM } \\
\left(\mathrm{g} \cdot \mathrm{kg}^{-1}\right)\end{array}$ & $\begin{array}{l}\text { Flesh DM } \\
\left(\mathrm{g} \cdot \mathrm{kg}^{-1}\right)\end{array}$ \\
\hline 1 & CRAW-AC22 & Breeding & 12 & $2,930.7$ & 963.9 & 3.0 & 262 & $\mathbf{1 8 9}$ \\
\hline 2 & CRAW-AF34 & Breeding & 12 & $1,584.8$ & 716.7 & 2.2 & 232 & 169 \\
\hline 3 & CRAW-AF42 & Breeding & 11 & $1,742.8$ & $\mathbf{2 1 8 . 0}$ & $\mathbf{8 . 0}$ & 207 & 144 \\
\hline 4 & CRAW-AG90 & Breeding & 12 & $2,337.4$ & 837.0 & 2.8 & 217 & 148 \\
\hline 5 & CRAW-AG94 & Breeding & 12 & $3,513.4$ & $1,273.9$ & 2.8 & 215 & 154 \\
\hline 6 & Pilot & Dessert & 12 & $3,142.8$ & 708.9 & 4.4 & 240 & 162 \\
\hline 7 & Gala & Dessert & 12 & $4,012.0$ & 812.0 & 4.9 & 214 & 146 \\
\hline 8 & Jonagold & Dessert & 12 & $5,023.3$ & $1,325.4$ & 3.8 & 248 & 169 \\
\hline 9 & Golden Delicious & Dessert & 12 & $\mathbf{1 , 2 9 8 . 8}$ & 502.8 & 2.6 & 212 & 146 \\
\hline 10 & Pinova & Dessert & 12 & $2,082.4$ & 567.8 & 3.7 & 206 & 157 \\
\hline 11 & Rubinstep & Dessert & 11 & $3,269.4$ & 558.0 & 5.9 & 217 & 139 \\
\hline 12 & Topaz & Dessert & 12 & $3,174.9$ & 688.4 & 4.6 & 218 & 152 \\
\hline 13 & Reinette Dubois & Dessert & 11 & $3,217.4$ & $1,043.1$ & 3.1 & 222 & 151 \\
\hline 14 & President Roulin & Dessert, cooking & 11 & $2,926.7$ & $1,033.5$ & 2.8 & $\mathbf{1 6 4}$ & $\mathbf{1 2 0}$ \\
\hline 15 & Reinette Hernaut & Dessert & 11 & $3,129.6$ & 864.2 & 3.6 & 206 & 132 \\
\hline 16 & Reinette Waleffe & Dessert & 12 & $4,396.5$ & $1,436.9$ & 3.1 & 255 & 170 \\
\hline 17 & P. Van Dievoet & Dessert, cooking & 11 & $4,233.4$ & $1,754.4$ & 2.4 & 211 & 153 \\
\hline 18 & Gueule de mouton & Cider & 12 & $4,348.5$ & $1,445.7$ & 3.0 & 246 & 160 \\
\hline 19 & Kermerrien & Cider & 8 & $3,471.7$ & $\mathbf{2 , 6 3 1 . 6}$ & $\mathbf{1 . 3}$ & 213 & 159 \\
\hline 20 & Malus sylvestris & Wild species & 11 & $\mathbf{9 , 2 4 2 . 1}$ & $1,247.2$ & 7.4 & $\mathbf{2 7 4}$ & 170 \\
\hline Bold & refer to & & & & \\
\hline
\end{tabular}

Bolds refer to the highest and lowest values - les chiffres en gras indiquent les valeurs les plus hautes et les plus basses. 
peel; consequently, the peel sample should therefore rather be considered as the epidermal zone of the apple. To evaluate its thickness, the so-called 'peel' was measured for five fruits of the 'Gala' variety. Each sample peel was measured 20 times using a sliding calliper (Mitutoyo). The mean thickness values were $0.62,0.52,0.77,0.56$, and $0.59 \mathrm{~mm}$ for the five fruits respectively, leading to the calculation of an average of $0.61 \pm 0.10 \mathrm{~mm}$ for the peel thickness. The flesh and peel of each fruit were lyophilized and reduced in a fine homogeneous powder with a blender. The fresh and dry weights of all samples were measured in order to determine the dry matter (DM) content, expressed in $\mathrm{g} \cdot \mathrm{kg}^{-1}$. Lyophilized product $(1 \mathrm{~g})$ was extracted with $2 \mathrm{ml}$ of methanol and the total phenolic compounds (TPC) were determined using Folin-Ciocalteau with slight modifications (Slinkard \& Singleton, 1977). The TPC content was expressed as gallic acid equivalents (GAE) in $\mu \mathrm{g} \cdot \mathrm{g}^{-1}$ fresh weight (FW). Results of the TPC and DM contents are presented as mean values calculated using the arithmetic mean of the samples. All actions (peeling, cutting) included in the preparation of the samples were realized in a very short time to avoid oxidation reactions.

\subsection{Calibration and validation methods}

The TPC and DM values determined in the peel and flesh powders were subsequently related to NIR spectra of the fresh fruits. The database was first split into a calibration and validation set. The split was achieved by ranking fruits in terms of polyphenol content and assigning one fruit in every three to the validation set. This resulted in a calibration set with a higher number of samples than the validation set. In a first step, only the fruits of the calibration set were used to build the calibration models. In a second step, the fruits of the validation set were used to test the performance of the models. This methodology produced two sets which were statistically almost identical, including an independent test set consisting of fruits which were not included in the calibration step. Calibration models were built using the Partial Least Square (PLS) method regression with the Winisi III package (Infrasoft International LLC, USA). The spectral pre-treatments Standard Normal Variate plus Detrend correction (SNVD) and first derivative were applied. The performance of the models was estimated using the following statistics: Standard Deviation (SD), Standard Error of Calibration (SEC), Standard Error of Prediction (SEP), coefficient of determination of calibration $\left(\mathrm{R}^{2} \mathrm{cal}\right)$, coefficient of determination of validation $\left(\mathrm{R}^{2} \mathrm{val}\right)$, and the ratio of prediction to deviation $(\mathrm{RPD}=\mathrm{SD} / \mathrm{SEP})$. An RPD value between 2 and 2.5 indicates that coarse quantitative predictions are possible, and a value between 2.5 and 3 or above corresponds to good or excellent prediction accuracy (Nicolaï et al., 2007).

\section{RESULTS}

\subsection{Total phenolic compounds and dry matter content in apples}

Total phenolic compounds show great variability among the varieties maintained in the collections of the CRA-W (Table 1). Great variability of TPC in peel and flesh was observed: total phenolic compounds content in apple peel and flesh ranged from 1,298.8 to $9,242.1 \mu \mathrm{g} \cdot \mathrm{g}^{-1}$ FW and from 218 to $2,631.6 \mu \mathrm{g} \cdot \mathrm{g}^{-1} \mathrm{FW}$ respectively (Table 1).

The ratio between peel TPC and flesh TPC showed extreme variability, ranging from 1.3 to 8 for 'Kermerrien' and 'CRAW-AF42' respectively (Table 1). The average ratio was 3.8 , which means that total phenolic compounds are on average almost four times higher in peel than in flesh. The scatter plot representing peel TPC $v s$ flesh TPC (Figure 1) clearly shows that the varieties 'Kermerrien'/'Malus sylvestris' have a higher mean phenolic content in flesh/peel than the other varieties. The varieties containing the highest TPC in the flesh are 'Reinette Waleffe', 'President Van Dievoet' and 'Gueule de mouton'. The genotype 'CRAW-AG94' from the breeding program of the CRAW and the commercial variety 'Jonagold' also have quite a high level of TPC content in their flesh. The wild species 'Malus sylvestris' stands out from the rest of the varieties for its very high phenolic compounds content in peel.

Dry matter content differed significantly between apple peel and flesh (Table 1). On average, the DM content of peel was $224 \mathrm{~g} \cdot \mathrm{kg}^{-1}$, while that of flesh was $155 \mathrm{~g} \cdot \mathrm{kg}^{-1}$. Dry matter content values in the present study varied greatly according to the cultivar, ranging from $164 \mathrm{~g} \cdot \mathrm{kg}^{-1}$ ('Président Roulin') to $274 \mathrm{~g} \cdot \mathrm{kg}^{-1}$ ('Malus sylvestris') in peel and $120 \mathrm{~g} \cdot \mathrm{kg}^{-1}$ ('Président Roulin') to $189 \mathrm{~g} \cdot \mathrm{kg}^{-1}$ ('CRAW-AC22') in flesh.

\subsection{Calibration of total phenolic compounds and dry matter in apples}

The database was divided into a calibration set $(n=160)$ and a validation set $(n=79)$ with the same statistical properties as for the total phenolic compounds and dry matter content (Table 2).

Some outliers were removed to develop calibration models for the TPC and DM content in peel and flesh powders, so that calibration models were developed using 152 samples and validation models with 77 samples (Table 3). The outliers, defined as samples for which the difference between the reference and predicted value was much larger than the SECV (t-outlier), were 
Table 2. Statistics (mean and standard deviation) of the calibration and validation sets for the total phenolic compounds (TPC) and dry matter (DM) content in peel and flesh powder of apples - Statistiques (moyenne et déviation standard) des sets de calibration et validation pour la teneur en polyphénols totaux (TPC) et en matière sèche (DM) dans la poudre de pelure et chair des pommes.

\begin{tabular}{|c|c|c|c|c|c|c|c|c|c|}
\hline & \multirow[b]{2}{*}{$\mathbf{N}$} & \multicolumn{2}{|c|}{ Peel TPC $\left(\mu \mathrm{g} \cdot \mathrm{g}^{-1} \mathrm{FW}\right)$} & \multicolumn{2}{|c|}{ Flesh TPC $\left(\mu \mathrm{g} \cdot \mathrm{g}^{-1} \mathrm{FW}\right)$} & \multicolumn{2}{|c|}{ Peel DM $\left(g \cdot \mathrm{kg}^{-1}\right)$} & \multicolumn{2}{|c|}{ Flesh DM $\left(\mathrm{g} \cdot \mathrm{kg}^{-1}\right)$} \\
\hline & & Mean & SD & Mean & SD & Mean & SD & Mean & SD \\
\hline Calibration set & 160 & $3,503.7$ & $1,811.8$ & $1,198.9$ & 947.3 & 224 & 28 & 154 & 17 \\
\hline Validation set & 79 & $3,356.2$ & $1,641.9$ & $1,126.7$ & 911.1 & 224 & 30 & 155 & 19 \\
\hline
\end{tabular}

Table 3. Performance of the calibration and validation models for the total phenolic compounds (TPC) and dry matter (DM) content in peel and flesh powder of apples - Performances des modèles de calibration et validation pour la teneur en polyphénols totaux (TPC) et en matière sèche (DM) dans la poudre de pelure et de chair de pommes.

\begin{tabular}{|c|c|c|c|c|c|c|c|c|c|}
\hline & \multicolumn{5}{|c|}{ Calibration } & \multicolumn{4}{|c|}{ Validation } \\
\hline & $\mathbf{N}$ & SECV & $\mathbf{R}^{2}$ cal & RPD & Factors & $\mathbf{N}$ & SEP & $R^{2}$ val & RPD \\
\hline \multicolumn{10}{|l|}{ Peel } \\
\hline $\mathrm{TPC}\left(\mu \mathrm{g} \cdot \mathrm{g}^{-1} \mathrm{FW}\right)$ & 152 & 560 & 0.93 & 3.3 & 9 & 77 & 531 & 0.91 & 3.1 \\
\hline $\mathrm{DM}\left(\mathrm{g} \cdot \mathrm{kg}^{-1}\right)$ & 152 & 5.8 & 0.98 & 5.0 & 9 & 77 & 6.5 & 0.94 & 4.8 \\
\hline \multicolumn{10}{|l|}{ Flesh } \\
\hline ТРC $\left(\mu \mathrm{g} \cdot \mathrm{g}^{-1} \mathrm{FW}\right)$ & 152 & 239 & 0.87 & 2.1 & 9 & 77 & 233 & 0.84 & 2.4 \\
\hline $\mathrm{DM}\left(\mathrm{g} \cdot \mathrm{kg}^{-1}\right)$ & 152 & 3.7 & 0.97 & 4.8 & 9 & 77 & 4.1 & 0.94 & 4.9 \\
\hline
\end{tabular}

SECV: standard error of cross-validation - erreur standard de validation croisée $\mathrm{R}^{2} \mathrm{cal}$ : coefficient of determination of calibration - coefficient de détermination de la calibration; RPD: ratio of prediction to deviation (= SD/SECV or SEP in the validation step) - rapport de prédiction de l'écart (= SD/SECV ou SEP au stade de la validation); SEP: standard error of prediction - erreur standard de la prédiction; $\mathrm{R}^{2} \mathrm{val}$ : coefficient of determination of validation - coefficient de détermination de la validation.

selected during the cross-validation passes. The limit was set at 2.5. It should be mentioned that samples with particularly high TPC content were not considered as outliers, since their content values were checked and validated; they were therefore maintained in the study. Models showed high coefficients of determination for the TPC content in both parts of the fruit (peel and flesh), with slightly higher coefficients for the peel $\left(\mathrm{R}^{2} \mathrm{cal}=\right.$ $0.93)$ than for the flesh $\left(\mathrm{R}^{2} \mathrm{cal}=0.87\right)$. The $\mathrm{RPD}$ value for the polyphenol content in the peel was 3.3, while it was somewhat lower in the flesh (2.1). According to the literature, the value obtained for the peel corresponded to a model with very good precision of prediction (Nicolai et al., 2007). For the DM content, very high coefficients of determination were observed $\left(\mathrm{R}^{2} \mathrm{cal}=0.98\right.$ and 0.97 for the peel and flesh, respectively). The RPDs were also high, with values of 5.0 and 4.8 for the peel and flesh respectively, which corresponded to models with very good precision of prediction. Using these calibration models, the plot of predicted values for the peel TPC $v s$ flesh TPC (figure not shown) was almost identical to that obtained with the reference values (Figure 1). Except for a few inversions of closely positioned varieties on the plot, the same relationships between the peel and flesh TPC of the varieties were obtained.

For the validation step, as expected, the coefficients of determination were slightly lower than those observed in the calibration (Table 3). A higher coefficient was observed for the polyphenol content in peel $\left(\mathrm{R}^{2} \mathrm{val}=\right.$ $0.91)$ than for the content in flesh $\left(R^{2} \mathrm{val}=0.84\right)$. The RPD value was 3.1 for the peel, whereas it reached 2.4 for the flesh. These results show that the precision of prediction is very good in peel but is not sufficient to allow quantitative prediction in flesh. Figure 2 shows the correlation between the predicted and the reference values of the TPC content in peel.

For the DM content, coefficients of determination were also lower than in the calibration step. However, they remained high $\left(\mathrm{R}^{2} \mathrm{val}=0.94\right.$ for both peel and flesh). As observed in the calibration step, the RPDs were high, although slightly lower, with values of 4.8 and 4.9 for the peel and flesh respectively. This suggests that the models are very precise and allow quantitative predictions to be made. Prediction of the dry matter content in peel is presented in figure 3.

\section{DISCUSSION}

\subsection{Total phenolic compounds and dry matter content in apples}

The amounts of phenolic compounds highlighted in this study seem large compared to the literature. Mean 


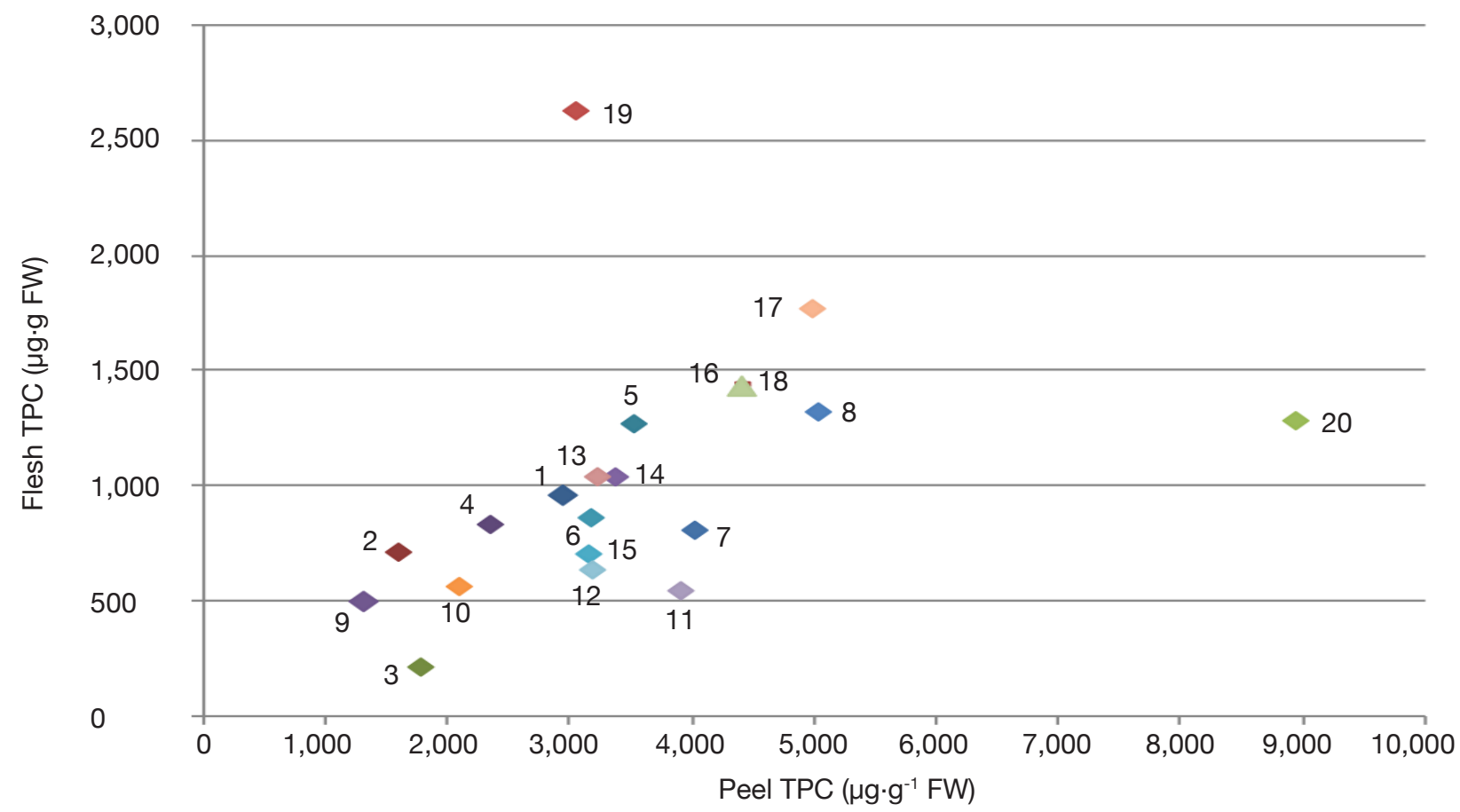

Figure 1. Scatter plot of the apple varieties according to their mean total phenolic compounds (TPC) in peel vs flesh powders (expressed in $\mu \mathrm{g} \mathrm{GAE} \cdot \mathrm{g}^{-1} \mathrm{FW}$ ) - Représentation des variétés de pomme en fonction de leur teneur en polyphénols totaux dans la poudre de chair en fonction de la teneur dans la poudre de pelure (exprimée en $\mu \mathrm{g} G A E \cdot g^{-1}$ poids frais).

Numbers refer to the variety number of table 1 - Le numéro se réfère au numéro de la variété indiquée dans le tableau 1.

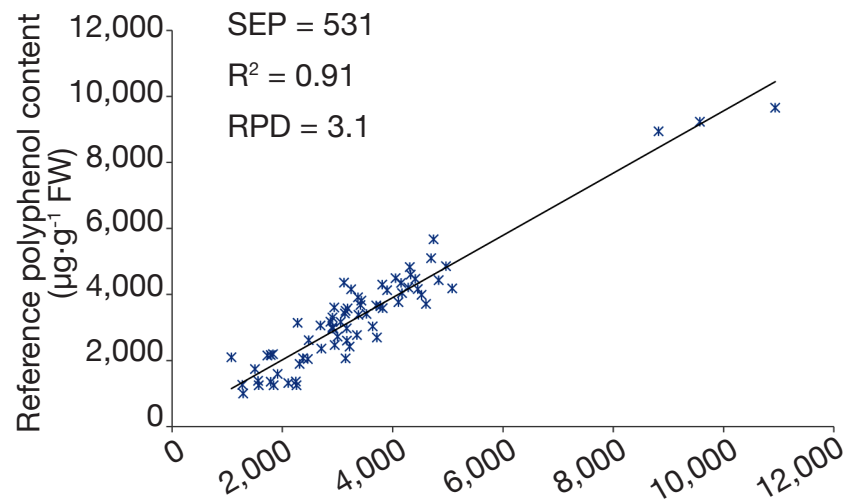

Predicted polyphenol content in peel powder $\left(\mu \mathrm{g} \cdot \mathrm{g}^{-1} \mathrm{FW}\right)$

Figure 2. Scatter plot for the determination of total phenolic compounds in peel powder of apples (expressed in $\left.\mu \mathrm{g} \mathrm{GAE} \cdot \mathrm{g}^{-1} \mathrm{FW}\right)$ for the validation set - Représentation de la teneur en polyphénols totaux prédite dans la poudre de pelure de pomme (exprimée en $\mu \mathrm{g} G A E \cdot g^{-1}$ poids frais) pour le set de validation.

content values of total polyphenols ranging from 662 to $2,119 \mu \mathrm{g} \cdot \mathrm{g}^{-1} \mathrm{FW}$ have been reported for eight of the most widely cultivated varieties (Vrhovsek et al.,

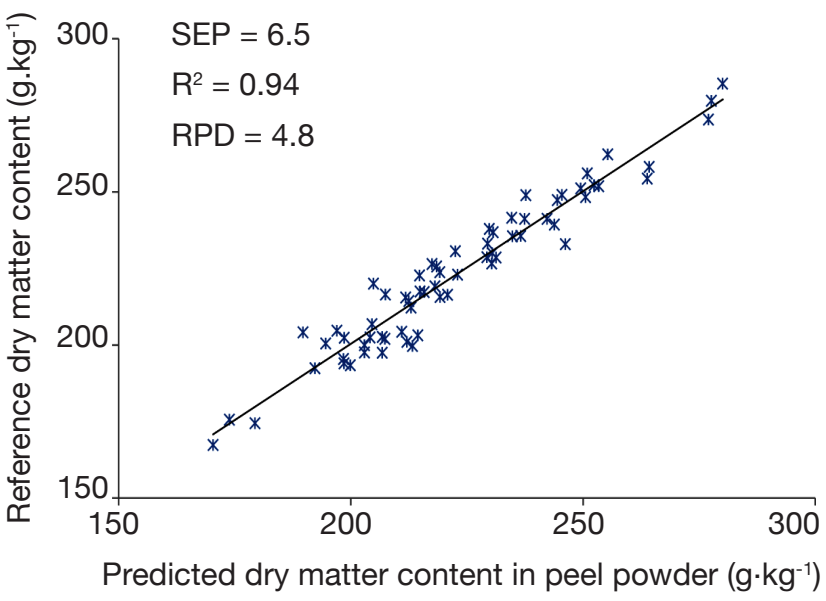

Figure 3. Scatter plot for the determination of dry matter content in peel powder of apples $\left(\mathrm{g} \cdot \mathrm{kg}^{-1}\right)$ for the validation set - Représentation de la teneur en matière sèche dans la poudre de pelure de pomme $\left(\mathrm{g} \cdot \mathrm{kg}^{-1}\right)$ pour le set de validation.

2004). The large range of values in this study may be explained by the broad diversity of varieties chosen, including a wild species ('Malus sylvestris') and a cider variety ('Kermerrien') with a very high content of phenolic compounds. The high concentration 
of total polyphenols and antioxidative potential of 'M. sylvestris' have been highlighted (Leontowicz et al., 2002). Cider apples are known to contain higher levels of phenolics than dessert apples, which gives them their characteristic bitter and astringent flavor. Very high concentrations of polyphenols ranging from 1 to $7 \mathrm{~g} \cdot \mathrm{kg}^{-1} \mathrm{FW}$ have been revealed in French cider apple varieties (Sanoner et al., 1999). A very wide concentration range has also been shown in Basque cider apple varieties (Alonso-Salces et al., 2004). Due to its particularly high polyphenols content (more than $3 \mathrm{~g} \cdot \mathrm{l}^{-1}$ ), 'Kermerrien' is referred to in the literature as belonging to the 'bitter' category within the cider varieties (Boré \& Fleckinger, 1997; Collin \& Crouzet, 2011).

Apart from 'M. sylvestris' and 'Kermerrien', the varieties with the highest phenolic content were 'Jonagold', 'President Van Dievoet', 'Reinette Waleffe', 'Gueule de Mouton', 'Gala' and the cultivar 'CRAW-AG94'. The varieties 'President Van Dievoet', 'Reinette Waleffe', 'Gueule de Mouton' are old varieties which are kept in the CRAW's collections. Old varieties present potentially interesting agronomic characteristics such as low susceptibility to scab (Lateur et al., 2001). The current results suggest that they could also contain good nutritional profiles due to their high phenolic compounds content. The high phenolic content of the commercial varieties 'Jonagold' and 'Gala' may be explained by their high TPC content in peel, which is likely to be related, at least partly, to the anthocyanins content of their red-colored skin.

The variability of TPC in peel and flesh observed among varieties has already been described in the literature. As it has previously been observed, apple peel contains more bioactive compounds than flesh (Lata, 2007; Carbone et al., 2011). A study of the phenolic composition of eleven apple genotypes showed significant differences between varieties, with total polyphenol content ranging from 502.2 to $1,294.9 \mu \mathrm{g} \cdot \mathrm{g}^{-1}$ in the peel and 100.5 to $807.5 \mu \mathrm{g} \cdot \mathrm{g}^{-1}$ in the flesh of apples (Khanizadeh et al., 2007). Total phenolics concentrations varying from $3,050 \mu \mathrm{g} \cdot \mathrm{g}^{-1}$ to $9,540 \mu \mathrm{g} \cdot \mathrm{g}^{-1}$ for the peel have also been demonstrated (Lata \& Trampczyńska, 2008). This highlights the nutritional interest of the whole fruit including the peel, which is generally discarded by consumers through the peeling of the apple.

The ratio between peel and flesh is consistent with the findings of other research reporting that, depending on the cultivar, apple peel contains several times more TPC than the pulp (Hassimotto et al., 2005; Drogoudi et al., 2008). The results showed that the 'Kermerrien' variety has a higher mean phenolic content than the other varieties, presenting a higher content of phenolics in flesh. As discussed above, 'Kermerrien' is a variety used in cider production which is not palatable for direct consumption. The quite high level of TPC in the flesh of the genotypes 'CRAW-AG94' and the variety 'Jonagold' is particularly interesting, since the consumption of an apple consists mainly of the consumption of flesh tissue, even when the peel is not discarded. Consequently, varieties with a high TPC content in flesh constitute good sources of nutrients and should be promoted to improve the intake of bioactive compounds in healthy diet. The position of the wild species 'Malus sylvestris', which stands out from the rest of the varieties, is consistent with the findings of a previous investigation (Leontowicz et al., 2002).

Values for DM in peel and flesh observed in this study are consistent with the literature. Values of $229 \mathrm{~g} \cdot \mathrm{kg}^{-1}$ and $159 \mathrm{~g} \cdot \mathrm{kg}^{-1}$ in peel and whole apple fruit respectively have been reported by Lata et al. (2005).

\subsection{Calibration of total phenolic compounds and dry matter in apples}

The better results obtained for the peel compared to the flesh may be related to the information revealed by the NIR spectra. The penetration of NIR radiation into fruit tissue decreases exponentially with the depth. A penetration depth of up to $4 \mathrm{~mm}$ in the $700-$ $900 \mathrm{~nm}$ range and between 2 and $3 \mathrm{~mm}$ in the $900-$ $1,900 \mathrm{~nm}$ range for apple fruits has been demonstrated (Lammertyn et al., 2000). NIR radiation is therefore likely to give chemical information related mainly to the epidermal zone (peel) and, to a lesser extent, to the underlying flesh. The greater precision of calibration/ prediction in the peel may also be related to the higher concentration of phenolics in the peel than in the flesh.

The effect of the peel on the NIR absorbance spectra has generally been investigated by measuring peeled and unpeeled fruits (Lu et al., 2000; López et al., 2014). By contrast, in this study the spectra of intact fruits, i.e. unpeeled apples, were related to the composition of their peel and flesh separately. As explained above, the spectra of the whole fruits contain information relating to the epidermal zone and, to a certain extent, to the underlying flesh, which probably limits the precision of the determination of the components of peel and flesh separately. The contribution of flesh or peel absorption to the overall light absorption spectra, and therefore to the precision of prediction models developed for peel and flesh separately, is difficult to estimate. In another study, the determination of pigment content in peel extracts using reflectance spectroscopy (in the 400$800 \mathrm{~nm}$ range) on whole apple fruits was investigated (Merzlyak et al., 2003). It was concluded that reflectance spectroscopy is a suitable and sensitive tool for non-destructive determination of the carotenoids, chlorophyll and anthocyanins content of peel.

Comparison to the literature is not easy, since NIRS has rarely been studied for the determination 
of phenolic compounds content in apples. In addition, methods of polyphenol determination and expression may vary in different studies. However, compared to the existing literature, the current models developed to determine the TPC content of apples using NIRS are quite good in general, and very good in relation to apple peel in particular. In a recent study the total phenol content in two varieties was predicted using a Vis-NIR portable system (Beghi et al., 2013). The results obtained varied according to the variety, with 'Stark Red Delicious' presenting better results $\left(\mathrm{R}^{2}=0.56 ; \mathrm{RMSECV}=0.06 \mathrm{mg}\right.$ catechin $\left.\cdot \mathrm{g}^{-1}\right)$ than 'Golden Delicious' $\left(\mathrm{R}^{2}=0.09\right.$; RMSECV $=0.10 \mathrm{mg}$ catechin $\left.\cdot \mathrm{g}^{-1}\right)$. The difference was attributed to the very low concentration of total phenols in 'Golden Delicious'. Comparison of calibration performance can be made with studies relating to other species. In a study focusing on tea leaves, the prediction model showed low accuracy $\left(\mathrm{R}^{2}=0.67 ; \mathrm{RPD}=1.7\right)$, which was attributed to the lack of specificity of the FolinCiocalteau method (Schulz et al., 1999). However, individual catechins were predicted with a varying degree of accuracy (RPD ranging from 2.7 to 6.3). In cocoa beans, an RPD value of 2.3 was obtained for the specific polyphenol (-)-epicatechin (Alvarez et al., 2012). More generally, a recent review showed the usefulness and efficacy of infrared spectroscopy in the analysis of antioxidant compounds in a wide range of agricultural products, foods and plants (Cozzolino, 2015).

Determination of dry matter content by NIRS in apples has been previously investigated. The present results for apple flesh are close to those reported in the study of McGlone et al. (2003). Based on 800$1,000 \mathrm{~nm}$ near-infrared spectrometric measurements, they investigated the use of DM content as a predictor of the post-storage soluble solids in apples ('Royal Gala' variety). They obtained very accurate predictive models $\left(\mathrm{R}^{2}>0.95 ; \quad \mathrm{RMSEP}<0.32 \%\right)$, whether at harvest or post-storage. The application of near-infrared transmission spectroscopy for the determination of DM has also been investigated (Lovász et al., 1994). It was shown that the calibration of this parameter is independent of the season, contrary to other quality parameters, and good prediction results were obtained $\left(\mathrm{R}^{2}=0.90 ; \mathrm{SEP}=0.58 \%\right)$. Recently, less strong predictive models for postharvest dry matter content using NIRS ( $\mathrm{R}^{2}$ of prediction varying between 0.63 and 0.86 and RPDs between 1.7 and 2.7) have been obtained (Travers et al., 2014). According to the authors, the complexity of absorbance spectra for DM and soluble solids content, plus their strong correlation, create uncertainty about what parameters the models are predicting and, consequently, current models cannot easily distinguish between soluble and non-soluble forms of carbohydrates. In Fuji apples,
Shi et al. (2008) highlighted that the determination of soluble solids content was greatly improved using the combination of PLSR with genetic algorithms (GAs). In his review, Alander et al. (2013) referred to numerous studies dealing with the use of NIRS spectroscopy to determine the soluble solids content in various fruits, including cherry and apricot (Carlini et al., 2000') and jujube (Zhang et al., 2008²). In avocado fruit, NIRS has been used to determine the water content of the mesocarp, leading to the postulation of on line sorting of fruits based on time to ripen (Blakey et al., 2009).

\section{CONCLUSIONS}

In conclusion, apples may contain a very high quantity of bioactive compounds such as phenolics. They are a very good source of nutrients in a healthy diet; however, it is difficult to precisely predict their intake as they are subject to significant varietal variability and to a variation of concentration between peel and pulp. More attention should be given to specific varieties ('old' or 'new' ones) presenting a higher level of bioactive compounds in flesh. This could be particularly helpful for improving the intake of bioactive compounds even if consumers remove the peel (in the case of both fresh fruit consumption and even processed apple products consumption). The high variability in phenolic compounds in peel and flesh among cultivars and Malus species may be useful for breeding programs and underlines the importance of germplasm conservation activities. In this context, genotypes presenting a higher level of bioactive compounds in flesh could be selected and used as parents in specific breeding programs. Unlike soluble solid content and firmness, the dry matter content is a parameter of which relatively little account is taken when studying the quality of apples. However, it is an important characteristic related to the fruit flavour and texture and its quality at harvest and after storage (McGlone et al., 2003; Palmer et al., 2010).

The originality of this work lies in the measurement of entire fruits by NIRS to determine the phenolic compounds and dry matter content in peel and flesh separately. Except for the lower RPD value for phenolic compounds in flesh, the high coefficients of determination and RPDs obtained in both the calibration and validation steps suggest that the models have good predictive power. NIRS models are able to

\footnotetext{
${ }^{1}$ Carlini P., Massantini R. \& Mencarelli F., 2000. Vis-NIR measurement of soluble solids in cherry and apricot by PLS regression and wavelength selection. J. Agric. Food Chem., 48, 5236-5242.

${ }^{2}$ Zhang S. et al., 2008. Robust model of fresh jujube soluble solids content with near-infrared (NIR) spectroscopy. Afr. J. Biotechnol., 11, 8133-8140.
} 
predict with accuracy the content of TPC and DM in apples, both parameters being of great importance for the quality and storability of fruits. This confirms the findings of previous works on the potential usefulness of NIRS to predict the polyphenol content of apples and to classify fruits according to their content in the context of breeding programs. The results obtained for the prediction of dry matter content suggest that NIRS could also be used for the accurate determination of this parameter, which has often been neglected in research into apple quality.

\section{Bibliography}

Alander J.T. et al., 2013. A review of optical nondestructive visual and near-infrared methods for food quality and safety. Int. J. Spectrosc., 2013, article ID 341402, 36 p.

Alonso-Salces R.M. et al., 2004. Polyphenolic profiles of Basque cider apple cultivars and their technical properties. J. Agric. Food Chem., 52, 2938-2952.

Alvarez C. et al., 2012. The use of near infrared spectroscopy to determine the fat, caffeine, theobromine and (-)-epicatechin contents in unfermented and sun-dried beans of Criollo cocoa. J. Near Infrared Spectrosc., 20, 307-315.

Awad M.A., de Jager A. \& van Westing L.M., 2000. Flavonoid and chlorogenic acid levels in apple fruit: characterisation of variation. Sci. Hortic., 83, 249-263.

Beghi R. et al., 2013. Apples nutraceutic properties evaluation through a visible and near-infrared portable system. Food Bioprocess Technol., 6, 2547-2554.

Blakey R.J., Bower J.P. \& Bertling I., 2009. Influence of water and ABA supply on the ripening pattern of avocado (Persea americana Mill.) fruit and the prediction of water content using Near Infrared Spectroscopy. Postharvest Biol. Technol., 53, 72-76.

Bobelyn E. et al., 2010. Postharvest quality of apple predicted by NIR-spectroscopy: study of the effect of biological variability on spectra and model performance. Postharvest Biol. Technol., 55, 133-143.

Boré J.-M. \& Fleckinger J., 1997. Pommiers à cidre. Variétés de France. Paris : INRA.

Boyer J. \& Liu R.H., 2004. Apple phytochemicals and their health benefits. Nutr. J., 3, 5 .

Bureau S., Scibisz I., Le Bourvellec C. \& Renard C.M.G.C., 2012. Effect of sample preparation on the measurement of sugars, organic acids, and polyphenols in apple fruit by mid-infrared spectroscopy. J. Agric. Food Chem., 60, 3551-3563.

Carbone K. et al., 2011. Phenolic composition and free radical scavenging activity of different apple varieties in relation to the cultivar, tissue type and storage. Food Chem., 127, 493-500.

Collin S. \& Crouzet J., 2011. Polyphénols et procédés : transformation des polyphénols au travers des procédés appliqués à l'agro-alimentaire. Paris: Tec \& Doc Lavoisier.

Cozzolino D., 2015. Infrared spectroscopy as a versatile analytical tool for the quantitative determination of antioxidants in agricultural products, foods and plants. Antioxidants, 4, 482-497.

Drogoudi P., Michailidis Z. \& Pantelidis G., 2008. Peel and flesh antioxidant content and harvest quality characteristics of seven apple cultivars. Sci. Hortic., 115, 149-153.

FAO (Food and Agriculture Organization of the United Nations), 2013. FAOSTAT, http://faostat3.fao.org, (October 2013).

Hassimotto N.M.A., Genovese M.I. \& Lajolo F.M., 2005. Antioxidant activity of dietary fruits, vegetables and commercial frozen fruit pulps. J. Agric. Food Chem., 53, 2928-2935.

Hyson A.A., 2011. Comprehensive review of apples and apple components and their relationships to human health. Adv. Nutr., 2, 408-420.

Khanizadeh D.S. et al., 2007. Phenolic composition and antioxidant activity of selected apple genotypes. J. Food Agric. Environ., 5, 61-66.

Lammertyn J., Peirs A., De Baerdemaeker J. \& Nicolaï B., 2000. Light penetration properties of NIR radiation in fruit with respect to non-destructive quality assessment. Postharvest Biol. Technol., 18, 121-132.

Lata B., 2007. Relationship between apple peel and the whole fruit antioxidant content: year and cultivar variation. J. Agric. Food Chem., 55, 663-671.

Lata B., Przeradzka M. \& Bińkowska M., 2005. Great differences in antioxidant properties exist between 56 apple cultivars and vegetation seasons. J. Agric. Food Chem., 53, 8970-8978.

Lata B. \& Trampczyńska A., 2008. Relationship between apple bioactive compounds after harvest and their fate in cold stored fruits. Acta Sci. Pol.- Hortorum cultus, 7, 89-99.

Lateur M., 2003. The integration of different sectors is a key factor for the conservation, evaluation and utilization of our Belgian fruit tree biodiversity. Bull. Inst. R. Sci. Nat. Belg. Biol., 73, 75-95.

Lateur M. \& Populer C., 1994. Screening fruit tree genetic resources in Belgium for disease resistance and other desirable characters. Euphytica, 77, 147-153.

Lateur M. et al., 2001. La résistance aux maladies, clé de la culture du pommier en production intégrée et en agriculture biologique. Fruit Belg., 494, 181-189.

Lattanzio V., 2003. Bioactive polyphenols: their role in quality and storability of fruit and vegetables. J. Appl. Bot., 77, 128-146.

Lee K.W. et al., 2003. Major phenolics in apple and their contribution to the total antioxidant capacity. J. Agric. Food Chem., 51, 6516-6520.

Leontowicz H. et al., 2002. Comparative content of some bioactive compounds in apples, peaches and pears and 
their influence on lipids and antioxidant capacity in rats. J. Nutr. Biochem., 13, 603-610.

López A., Jarén C. \& Arazuri S., 2014. Analysis of the influence of the skin on the near infrared absorbance spectra of potato tubers. NIR News, 25, 6-8.

Lovász T., Merész P. \& Salgó A., 1994. Application of near infrared transmission spectroscopy for the determination of some quality parameters of apples. J. Near Infrared Spectrosc., 2, 213-221.

Lu R., Guyer D.E. \& Beaudry R.M., 2000. Determination of firmness and sugar content of apples using near-infrared diffuse reflectance. J. Texture Stud., 31, 615-630.

Markowski J. \& Plocharski W., 2006. Determination of phenolic compounds in apples and processed apple products. J. Fruit Ornam. Plant Res., 14, 133-142.

McGlone V.A., Jordan R.B. \& Martinsen P.J., 2002. Vis/ NIR estimation at harvest of pre- and post-storage quality indices for 'Royal Gala' apple. Postharvest Biol. Technol., 25, 135-144.

McGlone V.A., Jordan R.B., Seelye R. \& Clark C.J., 2003. Dry-matter - a better predictor of the post-storage soluble solids in apples? Postharvest Biol. Technol., 28, 431-435.

Mehinagic E. et al., 2003. Relationship between sensory analysis, penetrometry and visible - NIR spectroscopy of apples belonging to different cultivars. Food Qual. Preference, 14, 473-484.

Merzlyak M.N., Solovchenko A.E. \& Gitelson A.A., 2003. Reflectance spectral features and non-destructive estimation of chlorophyll, carotenoid and anthocyanin content in apple fruit. Postharvest Biol. Technol., 27, 197-211.

Nicolaï B.M. et al., 2007. Nondestructive measurement of fruit and vegetable quality by means of NIR spectroscopy: a review. Postharvest Biol. Technol., 46, 99-118.

Palmer J.W., Harker F.R., Tustin D.S. \& Johnston J., 2010. Fruit dry matter concentration: a new quality metric for apples. J. Sci. Food Agric., 90, 2586-2594.

Park B. et al., 2003. Near-infrared diffuse reflectance for quantitative and qualitative measurement of soluble solids and firmness of Delicious and Gala apples. Trans. ASAE, 46, 1721-1731.

Paz P. et al., 2009. Evaluating NIR instruments for quantitative and qualitative assessment of intact apple quality. J. Sci. Food Agric., 89, 781-790.

Peirs A. et al., 2003. Effect of biological variability on the robustness of NIR models for soluble solids content of apples. Postharvest Biol. Technol., 28, 269-280.

Pissard A. et al., 2012. Classical and NIR measurements of the quality and nutritional parameters of apples: a methodological study of intra-fruit variability. Biotechnol. Agron. Soc. Environ., 16, 294-306.

Pissard A. et al., 2013. Non-destructive measurement of vitamin $\mathrm{C}$, total polyphenol and sugar content in apples using near-infrared spectroscopy (NIRS). J. Sci. Food Agric., 93, 238-244.
Planchon V., Lateur M., Dupont P. \& Lognay G., 2004. Ascorbic acid level of Belgian apple genetic resources. Sci. Hortic., 100, 51-61.

Sanchez N.H., Lurol S., Roger J.M. \& Bellon-Maurel V., 2003. Robustness of models based on NIR spectra for sugar content prediction in apples. J. Near Infrared Spectrosc., 11, 97-107.

Sanoner P. et al., 1999. Polyphenol profiles of French cider apple varieties (Malus domestica sp.). J. Agric. Food Chem., 47, 4847-4853.

Schulz H. et al., 1999. Application of near-infrared spectroscopy to the simultaneous prediction of alkaloids and phenolic substances in green tea leaves. J. Agric. Food Chem., 47, 5064-5067.

Shi B. et al., 2008. Study of genetic algorithms-based NIR wavelength selection for determination of soluble solids content in Fuji apples. J. Food Qual., 31, 232-249.

Slinkard K. \& Singleton V.L., 1977. Total phenol analysis: automation and comparison with manual methods. Am. J. Enol. Viticult., 16, 144-158.

Travers S., Bertelsen M.G. \& Kucheryavskiy S.V., 2014. Predicting apple (cv. Elshof) postharvest dry matter and soluble solids content with near infrared spectroscopy. J. Sci. Food Agric., 94, 955-962.

Tsao R., Yang R., Young J.C. \& Zhu H., 2003. Polyphenolic profiles in eight apple cultivar using high-performance liquid chromatography (HPLC). J. Agric. Food Chem., 51, 6347-6353.

Vander Sluis A.A.,Dekker M.,de Jager A.\& Jongen W.M.F., 2001. Activity and concentration of polyphenolic antioxidants in apple: effect of cultivar, harvest year, and storage conditions. J. Agric. Food Chem., 49, 36063613.

Van der Sluis A.A., Dekker M., Skrede G. \& Jongen W.M., 2002. Activity and concentration of polyphenolic antioxidants in apple. 1. Effect of existing production methods. J. Agric. Food Chem., 50, 7211-7219.

Verberic R. et al., 2005. Phenolic compounds in some apple (Malus domestica Borkh.) cultivars of organic and integrated production. J. Sci. Food Agric., 85, 16871694.

Vrhovsek U., Rigo A., Tonon D. \& Mattivi F., 2004. Quantitation of polyphenols in different apple varieties. J. Agric. Food Chem., 52, 6532-6538.

Wojdylo A., Oszmianski J. \& Laskowski P., 2008. Polyphenolic compounds and antioxidant activity of new and old apples varieties. J. Agric. Food Chem., 56, 6520-6530.

Zude M. et al., 2006. Non-destructive tests on the prediction of apple fruit firmness and soluble solids content on tree and in shelf life. J. Food Eng., 77, 254-260. 